\title{
School Integration in South African Multicultural Schools: Policy Challenges
}

\author{
Pertunia Rebotile Machaisa
}

\author{
Department of Educational Leadership and Management, College of Education, University of South Africa
}

Email: machapr@unisa.ac.za

\section{Doi:10.5901/mjss.2014.v5n23p1590}

\begin{abstract}
A study was undertaken to examine policy opportunities and challenges on school integration in South African multicultural schools. The literature review revealed that policies on school integration presents opportunities but also do not absolutely address the challenges of the diverse cultural groups that are bound together in a school setting. In order to support or reject the findings of the literature study, qualitative research was conducted. The research results indicated that although there are fundamental opportunities provided by educational policies, there are also some serious challenges that exist between policy formulation and its implementation. This article explores in particular these policy challenges on school integration with the aim of providing a clear understanding of this phenomenon of policy though the use of critical race theory.
\end{abstract}

Keywords: Transformation, school integration, desegregation, multicultural education, critical race theory

\section{Introduction}

To appreciate the value of and conduct any research on school integration, one has to understand the history of South Africa (Nkomo, Chisholm \& Mckinney, 2004). The dawn of democracy paved the way towards transformation. This meant initiating remedial strategies to redress and eliminate past imbalances and inequalities in all spheres of government. Education was not immune to this rigorous transformation and school integration was seen as one important transformation tool for the education system. This was done to speed up change, which took place after the new government came into power in 1994. As one of the initiatives, mono-racial / cultural schools were de-racialised in order to open doors to learners of different cultures and races. This led to the desegregation of schools to counteract segregation that was created by the previous regime. Consequently, government had a formidable policy formation task in tackling this desegregation processes to pave the way for transformation of multicultural schools, thereby promoting racial and cultural integration in these schools.

The current South African educational system is designed with the main objective of replacing the fragmented and deeply discriminatory education system with a unified national system underpinned by democracy, equality, redress, transparency and participation (Department of Education, 2001). This system is one based on inclusion, social justice, nation building, and equity (Chisholm, 1997). The government was faced with a challenge to overcome the devastation of apartheid and provide a system of education that builds democracy, human dignity, equality and social justice (Department of Education, 2001). Subsequently, the government instigated the process of transformation in political, social, economic, cultural and educational areas. This process was begun through the drafting and introduction of legislation and policies in all sectors of the government to aid and catalyse this transformation. The first, fundamental and significant law was the Constitution of the Republic of South Africa which was adopted as the supreme law of the land on 6 May 1996 (Mda \& Mothata, 2000). It laid the foundation for transformation and hope for all South Africans irrespective of race, culture, religion, and gender and all other components of diversity in South Africa. It is obviously part of growth and development that was necessary to reflect the willingness of the state to deal positively with transformation. As emphasised by Fleisch (2002: 1) the role of the state in school change has emerged as a major research theme in education scholarship.

Additionally, Education White Paper on Education and Training was introduced in 1995 (Department of Education, 1995). This was a transformation mechanism that pressurised one-race schools to accommodate, enrol and facilitate the involvement of other cultures and races (Education White Paper 1, 1995). The National Education Policy Act (1996) and the Education White Paper 1 (1995) were striving to establish equal education for all learners without discrimination. One other document by the Department of Education on Education for all - 2005 Country status report: South Africa played an immense role in making sure that all learners are assured education from early childhood, primary and compulsory 
education to adult basic education. Subsequently, other laws such as the South African Schools Act 84 (1996), Employment Equity Act 55 (1998) and Language in Education Act (1997) were also drafted. The establishment of the Directorate on Race and Values in Education, the South African Human Rights Commission were established to monitor the progress of the new initiatives and to address the segregation issues that existed in the pre-democratic administration.

According to previous studies conducted by different institutions and individuals after 1994 in the few years after democracy, this process has not been an easy one (Naidoo, 1996; Carrim, 1998; Zafar, 1998; Vally \& Dalamba, 1999; Sekete, Shilubane \& Moila, 2001; Sujee, 2003). In spite of these policy measures which are regarded as positive initiatives and opportunities, there still remains a worrying concern about the challenge in terms of the gap that exists between policy formulation and its implementation. Since education offers the best opportunity to make changes that will affect all fields, this is particularly disturbing. Irrespective of the drastic policy initiatives, there still is uncertainty and vagueness about the implications in schools and precise processes to guide the implementation thereof. This is evident in reported cases of racism and outright discrimination that is still report in the media in some schools in South Africa. School managers and teachers are still faced, after 19 years of democratic rule, with challenges to implement the legislation put together by the new government towards desegregation and integration that is geared towards the transformation of education. This should undoubtedly be a continuous process because of the nature of South Africa as a diverse society.

In this article an attempt is made to first understand necessity of school integration at the same time understanding positive opportunities as stipulated in different policies geared towards school integration in South African schools. Importantly the discussion of critical challenges of these policies on school integration will also be detailed. Critical race theory will be used to understand the nature of these challenges as presented by the policies under discussion.

\section{The Necessity of School Integration}

The theme of education and social change has been explored in depth both internationally and locally. A veritable industry has emerged in the last two decades around different ways of defining, researching, analysing and understanding processes of change in and around education (Chisholm, 2004). With transformation being the point of departure, it is of importance to see how educational change has had an impact on the whole system of development in South Africa. As a young democracy as compared to most African countries, South Africa has experienced extensive political transformation which resulted in the restructuring of the education system. In the first phase of education transformation, the state placed more emphasis on developing legislation and policies to enhance and facilitate change and also to establish organisations and institutions to create conditions for effective transformation which were going to make a tremendous contribution to the education of the country. Chisholm (1997) elaborates that these educational policies for a new South Africa showed remarkable resemblance with international trends which are reshaped in terms of South Africa's specific social and educational make-up This was very challenging and overwhelming for a new educational sphere and did not continue, till to date, without problems

Research on school integration is significant in South Africa because of the diversities present within South African society at large. Schools as organisations within these societies are highly affected by these diversities and must continuously find ways to function within these complex and mostly ignored issues. The contribution of this article does not only relate to South Africa but should be a critical reflection on school integration issues especially in countries with history of discrimination and segregation. The debates should continue to look for strategies to facilitate the process on an international level and assist with effective implementation of policies in this regard in specific countries. School integration is a complex phenomenon and to some extent very sensitive issue to tackle especially when particularly focusing on race and culture. Several studies have been conducted in South Africa (Naidoo, 1996; Carrim, 1998; Zafar, 1998; Ntshingila Khosa, 1999; Vally \& Dalamba, 1999; Mda, 2000, Sekete, Shilubane \& Moila, 2001; Sujee, 2003; Nkomo, et al., 2004; Moletsane, et al. , 2004; Soudien, 2004; Ndimande, 2005; 2010 and many others that researched on the topic later. These studies looked at school integration as a process after 1994 but not specifically at policy challenges as presented in these article. Some present great policy opportunities as initiatives but ignore the gaps that are presented by these same policies.

This article does not only intend to highlight opportunities and present challenges on school integration policies but also to open a debate about the effectiveness of these policies and clarify realistic goals for effective school integration process in former one race schools. The article further encourages continuous research on school integration since not much has changed since 2000 and 2008. 


\section{Theoretical Framework}

In an attempt to answer the main concerns in this article, the Critical Race Theory (CRT) will be used. CRT argues that the logic and structure of conventional law grow out of power relationships of the society, and as a consequence, the oppressed will never be well served by the law (Ladson-Billings, 2009). According to West (1995) critical race theory "is a gasp of emancipatory hope that law serve liberation rather than domination". CRT is also defined as a movement which is a collection of activists or scholars interested in studying transformation of relationships among race, racism and power (Delgado \& Stefanic, 2001). The theory originated as a response to what legal scholars termed Critical Legal Studies (CLS) as a way of challenging the limited way issues of race, gender and class were thought in law school. CLS takes its perspectives from the social theories of Marx, Engels, Weber, Horkheimer, Marcuse and others who are associated with the Frankfurt school.

CLS proponents talk about inherently political nature of the law and its inability to ever be neutral or value free (Ladson-Billings, 2009). She also states that CLS began in 1977 during a conference at the University of WisconsinMadison (USA) where legal scholars were active during the 1960 civil movement looked at ways to infuse the law with issues of concerns around struggles on race, gender and anti-war. These gave birth to CRT as a new way of tackling issues of legal nature and how the law can be used to bring on stability in a particular environment. This theory is relevant in this article as it speaks to the policy formulations and implications that were brought about by the new political regimes to alleviate the imbalances of the past that were previously prevalent in what used to be one race schools. Amongst other arguments, this theory states that the law is like politics. There is a common notion that since the law is made by human beings, it is subjected to the same shortcomings and imperfections of human beings. Policy frameworks that are presented in this paper present to some extent these shortcomings, gaps and vagueness to support this argument.

\section{The Stipulations of Different Policies on School Integration}

The following section highlights the main policy initiatives that were and are still geared towards education transformation in South Africa. In the context of this article, these initiatives were made to catalyse school integration in former one race schools.

\subsection{The Constitution of the Republic of South Africa Act 108 of 1996}

The Constitution of the Republic of South Africa is the highest law of the land. It is regarded as the "supreme law" of the country, the first and basic law of the new South Africa after 1994. It contains all the fundamental principles according to which South Africa is to be governed. In the founding provision it explains the expectations of the democratic state, which should be non-racist and non-sexist while at the same time respecting the rights of all citizens. South Africa as a multicultural society needed a sound Constitution to create such an environment. Therefore, the values and principles in the founding provision directly deal with the issue (Bray, 2004). Of particular importance is the Bill of Rights (Chapter 2), which mentions all the rights and freedoms that are to be protected, promoted and enforced by the government, individuals and groups (Mothata, 2000).

The Constitution as the basis for all laws and each and every aspect of South African society is also a guiding tool for educational matters. It has particular reference to making sure that our schools are not seen as isolated and separated based on race, culture, disability or any other aspects of diversity. The government in its plan used the Constitution to ensure equality in our education system. The Bill of Rights section 9, the equality clause, states clearly that "Everyone is equal before the law and has the right to equal protection and benefit of the law". It further exclaims that the state or any person may not unfairly discriminate directly or indirectly against anyone on one or more grounds, including race, gender, sex, pregnancy, marital status, ethnic or social origin, colour, sexual orientation, age, disability, religion, conscience, belief, culture, language and birth. Also, in Section 29 (1) it guarantees access to a basic education for all when it states that "everyone has a right to basic education, including adult basic education". The Constitution's purpose on integration is to unite the different and diverse constituent parts (groups) of the community into one South African nation (Bray, 2004) and most importantly to unite learners in South African schools. The main question remains, how should this be ensured? Who should be responsible and how will this be monitored? 


\subsection{Education White Paper 1 on Education and Training of 1995}

The White Paper on Education and Training of 1995 was the first official policy document in education published by the ANC-led government (Mothata, 2000). This policy was aimed at the integration of education and training and most importantly to instil equality and equity by redressing and eliminating the past imbalances through transforming the education system as a whole. The policy promises the provision of equity in education through proper training. This refers to all schools and to all learners, young and old. In tackling the legacy of the past, the White Paper maintains that the state has a central role to play in the provision of education and training although other civil society agencies should also facilitate the provision of learning opportunities to assist the state in this regard. The policy stresses the promotion of values underlying the democratic process and declaration of fundamental rights as in the Constitution (Greenstein \& Mabogoane, 1994). In addressing the inequalities of the past, the policy focuses on the equal provision of education opportunities to all children irrespective of race, gender, language, disability, and all other aspects of diversity in South African schools. This in itself promotes school desegregation.

The White Paper 1 was followed by the development and implementation of White Paper 2 entitled Organisation, Governance and Funding of Schools which was published in 1996. White Paper 2 was built on the principles of White Paper 1 and formed the basis of the South African Schools Act of 1996. Following this, in 1997, White Paper 3 on A Programme for Transformation of Higher Education was published. White Paper 3 was aimed at assessing the needs and challenges of higher education, focusing particularly on the unequal and inadequate distribution of access and opportunity for students (DoE, 1997). In May and July 2001, the Department of Education published White Papers 5 (Early Childhood Education) and 6 (Special Needs Education) respectively as part of continuous educational transformation.

\subsection{The National Education Policy Act (NEPA) Act 27 of 1996}

The objectives of this Act provide for:-

The determination of national education policy by the Minister of Education in accordance with principles in the Constitution and in this Act; the consultation to be undertaken prior to the determination of policy, and the establishment of certain bodies for the purpose of consultation; the publication and implementation of national education policy; and the monitoring and evaluation of education (DoE, 1996). The policy addresses among other issues, the organisation, management and governance of the national education system; the learner-educator ratio; compulsory school attendance; school age determination; language in education; and educational support services. The Act discusses the right to basic education of every person and equal access to educational institutions. It points out that every person must be protected against unfair discrimination within or by an education department or education institution on any ground. Issues such as language, religion, culture, gender equality, physical (dis)/ability, lifelong learning are highlighted. These issues are directly related to school integration.

\subsection{The South African Schools Act 84 of 1996}

The SASA, as it is popularly known, was passed by the National Education Department with the main aim of providing the uniform system for the organisation, governance and funding of schools. In its preamble it states that:

"...a new national system for schools which will redress past injustices in educational provision, provide an education of progressively high quality for all learners and in so doing lay a strong foundation for the development of all our people's talents and capabilities, advance the democratic transformation of society, combat racism and sexism and all other forms of unfair discrimination and intolerance..." (Preamble, SASA).

The preamble highlights important matters to be considered. Again non-discrimination, non-racist and non-sexist are mentioned. Schools were ordered through this legislation which was particularly developed for schools, not to discriminate in any way against any child. As with the Constitution and the National Policy Act, it promotes equality in education for all learners.

The Schools Act further discusses matters relating to admission, religious, language policies and code of conduct for learners without discrimination in any way. Issues of importance like school fees, suspension and expulsions, prohibition of corporal punishment, involvement of learners in the Learners' Representative Council, the roles and functions of the School Governing Bodies in public schools are discussed in this Act to serve as the guideline on how 
schools should be governed with respect, while recognising the values of a democratic state. Chapter Five of this document outlines the provisions for how the Independent schools are expected to operate and function in a democratic country. Chapter Six focuses on private schools and regulations to maintain equity, governance and regulations are set and explained.

\subsection{Employment Equity Act (EEA) 55 of 1998}

The main purpose of this Act is to achieve equity in the workplace by promoting equal opportunity and fair treatment in employment through the elimination of unfair discrimination; and instituting affirmative action measures to rectify the system through which previously certain groups were disadvantaged, in order to ensure equitable representation in all occupational categories and levels in the workplace (Mothata, 2000). The Act guards against any kind of discrimination by any employer and urges all employers to take steps to promote equal opportunities by eliminating unfair discrimination in any employment policy or practice (DoL, 1998). This Act helps in situations where previously one-race educators were the only ones employed to teach learners in a specific school. Now schools must open their doors to all teachers of all races, culture, language, gender, dis-/ ability or any other form of diversity to teach in any school of their choice without discrimination. Desegregation in schools refers not only to learners having to be mixed, but also educators, governing body members, administrative staff, and any other members of staff that work in a multicultural environment.

\subsection{Language in Education Policy (LiEP) of 1997}

LiEP must be read and understood in terms of the National Education Policy Act 27 of 1996 and the Constitution of the Republic of South Africa Act 108 of 1996. There are provisions in these laws, section 3(4) and 4 and Chapter 2, which respectively address issues of language in South African society. According to this policy, in terms of the Constitution, the government recognises that cultural diversity in South Africa is a valuable national asset. The LiEP therefore is intended to promote multilingualism, develop official languages and inculcate respect for all languages used in the country including South African Sign Language. To counter disadvantages resulting from the mismatch between home language and language of learning and teaching.

It has been observed that policy development and implementation to some extent play an important role in educational transformation. This section discussed briefly the South African educational policies that played a role in educations change before and after 1994. The South African government developed policies, laws, and regulations and, in some cases bodies, that dealt with, and to a greater extent still is dealing with, issues of diversity in all spheres of society. The process does not happen without problems. All the mentioned policies and legislation have had a direct impact on the implementation of school desegregation and integration as they addresses issues of equality, rights and freedoms for all learners, students and adults in any educational institution in South Africa.

All these policies reflect exceptional commitment on the side of the government of National Unity to transformation. They also present great opportunities for policy development in South Africa. They are arguably seen as excellent initiatives by many. The gap between policy and implementation is still a problem in South Africa even today. This is one of the major challenges for total transformation in all sectors of South Africa as a developing country. This is very critical in this article because the problems identified with policy implementation in education reflect on the argument of the study as a whole that South African education system is still faced with gaps, challenges and difficulties that will probably take countless years to be at least minimised if not at all eliminated. Nzimande (1997) explains that since 1990 when the government of national unity started formulating policies; there has been a tendency to become too narrowly focused on these policies while inadequate attention has been put on the broader theoretical and political questions and this, he stresses, this attitude needs to be corrected.

\section{Research Design and Methodology}

The research design for this study was structured in such a way that the participants who were carefully selected and the methods that were chosen complement each other so as to get reliable data. Cohen, et al. (2002) is of the view that research design is governed by the notion of 'fitness for purpose'. This, according to them means that the purpose of the research determines the methodology and the design of the research. They state that there is no single blueprint for planning research. At the end of it all, research design is a plan or strategy for conducting research. As a plan, it deals with matters such as selecting participants and preparing for data collection (Wiersma \& Jurs, 2005). This article used a qualitative research approach. 
A list of all schools in Johannesburg, Gauteng Province was acquired from the Gauteng Provincial Department of Education (GDE). From this list two school districts were selected, Johannesburg North (District 10) and Johannesburg South (District 11). Here purposive random sampling was used. Only multicultural and former one race schools were selected. The school population includes learners, teachers, the principal, administrative staff and other people who are working at the school and this is regarded as population in the context of this article.

Since the research conducted was focused on school managers (principals) and educators, it was obvious that the sampling frame would be all school principals and all teachers in these multicultural schools. There is one principal in each school, and the teachers are too many for all to be involved in the study, therefore specific teachers were identified in a carefully planned manner to represent the entire teaching body in all the schools. The educators in the schools had to be selected to make the sample more manageable and focused, this was done through quota sampling. According to Strydom, with this type of sampling, specific categories of persons are sampled. These categories can be gender, race, occupation and so forth (2005). Neuman, (2003) agrees by stating that here the population is divided into a number of categories and a sample drawn from each category. For this purpose, only six or fewer teachers were selected to be interviewed using the race and gender quota in each school.

Firstly, individual face-to-face (one-on-one) interviews were used to get information from the people who are directly involved and have first-hand information on the topic and on the progress made in the area of school integration. Secondly, group interviews, in the form of focus group discussions involving a group of respondents familiar with the topic and focus area were also used. The participants were encouraged through appropriate questioning to provide answers according to their best knowledge and understanding, and for the interviewer to formulate more questions based on specific themes or issues that were formulated beforehand. Both the individual and focus group discussions were semistructured and open ended. The data were captured with an audio recorder and later transcribed and analysed to answer the main questions of the research.

Semi-structured interviews were used. This type of interview gives the interviewer the opportunity to decide on the follow-up questions based on the respondents' answers. In this way the researcher can decide on the order and the wording of the questions even though the questions have been prepared beforehand. This is emphasised by Grinnell, Jr. and Williams (1990) "in semi-structured interviews we have prepared questions but also have the latitude in deciding the order and wording of the questions and whether follow-up questions should be asked". They also state that this type of interview is often used at the descriptive level of research.

Non-probability sampling procedure was used in this research. This means that purposive sampling strategy was used to get participants. The schools that were chosen for this project were selected for a specific purpose. That is, those that were formerly one-race and currently multiracial. Cohen, et al. (2002) mention that in non-probability sampling which is purposive, the researcher deliberately and purposely selects a particular section of the wider population to include in the sample Therefore, only these schools were involved in the study with the major purpose of addressing the main concerns of the study.

This sampling type is totally controlled by the data collector in determining the number of participants to be involved, their categories and for what purpose. This is supported by Strydom (2005) who states that selection of persons for inclusion in the sample rests totally with the fieldworker and, that there might be, to a certain extent, some subjectivity which can play a significant role. Nevertheless, this procedure was deemed necessary in this study because of the different racial groups in different schools which had to be included in the sample. All the participants were given an equal chance of being included in the sample.

Educators in every school were divided into their racial groups. The list of the educators in each school was obtained from the principal. From the racial groups identified on the list, educators were randomly selected and their names given to the principal. These educators were selected for focus group interviews. The purpose here was for all racial groups to be represented in the sample. The number of interviewees per school differed because of the varying number of teachers in each school. Therefore, the number of focus group interviewees was determined by the number of teachers in each school. At times gender was also used, although it was not a factor in this case. I tried where possible to make the sample representative according to race and gender. At the end of it all, not all schools met these criteria. The remaining teachers, approximately fifteen (15) at each school, were given questionnaires to complete.

From the individual interviews (8 principals), focus group interviews (34 teachers) and questionnaires (82), there was a total number of 124 participants that took part in the study and represented the sample for this research. All eight (8) school managers (principals) were interviewed. The questions were prepared with themes and important elements, as gathered from the literature and documents collected from schools, in mind. Appointments with the principals were arranged and all preparations made before the actual meetings. The venues were well-organised and consent was received from all the respondents beforehand. All interviews were scheduled for forty-five (45) minutes for each 
respondent, and an audio tape recorder was used to capture the data with the full consent of the interviewees.

Data analysis process is an immense step in any research and a challenge to researchers as it ought to be done carefully and given enough time because it must truly reflect the responses of the participants and most importantly not deviate from the original aims of the study. According to De Vos (2005), data analysis is a process of bringing order, structure and meaning to the mass of collected data. It is a messy, ambiguous, time-consuming, creative and fascinating process which does not proceed in a linear fashion. For this purpose, content analysis was used to analyse the data collected. According to Henning et al. (2004), this analysis helps the researcher to scour the data and look for related themes through coding and categorising. This type of analysis also examines words or phrases within a wide range of texts, including books, essays, interviews, speeches as well as informal conversation by examining the presence or repetition of certain words and phrases in the texts (Babbie \& Mouton, 2001).

\section{Research Findings and Discussion}

It is fact that pre-1994 policies were aimed at providing education for all as it was mentioned in the laws and legislation such as the White Paper on Education and Training (1995) and many others that followed it. The Constitution most importantly, laid the foundation for integration (Mda, 2000). These laws, I believe had a major impact on the whole transformation of education as a whole. These laws, legislation and policies should however not be accepted as unproblematic regarding their implementation particularly in schools. When the participants were asked if they thought the government policies helped in schools and particularly on their schools, they acknowledged and expressed appreciation of the assistance given by policies in the general governance and support of the school. The respondents use the policies as guidelines to make their school better. They are of the view that for the school to run smoothly, one needs policies to regulate school issues and the existing government policies do just that.

When asked about the direct impact of these policies on the process of integration, they mentioned that the policies help them to accommodate learners from all racial groups and not to discriminate in any way against any learners. According to them, these policies help to develop school policies that are of the same aspirations. There are however, some they do not notice any improvements regarding government policies with regards to what is directly taking place in schools. They are of the view that these policies do not really affect them, as most of the schools still follow their own traditions and morals, irrespective of the policies. This comment gives an indication that while some schools regard government policies as important tools to assist with change, there are still those who feel they would prefer to continue relying on the existing systems. They do not want to change the status quo in their schools.

While the participants acknowledged the influence of government policies on integration, they were also asked if they had specific school policies on integration in their respective schools. All stated that they did not have a specific policy on integration. Some are of the opinion that policies do not really help if situations remain the same. They feel that integration is not recognised in schools and it is only written on paper in terms of policies that circulate in schools. Others further highlighted that it was not easy to develop a policy on integration because they do not see colour in the learners. The majority of the principals feel that one cannot really develop a policy on integration since according to them it is a natural process and it will happen at its own pace. They believe that developing a policy is forcing integration and that policy on integration would not work.

\subsection{Teacher training on diversity and multiculturalism}

A significant portion of these research findings was on the training of the teachers. It is therefore necessary to recommend that the Department of Education initiate a new kind of teacher education, training and development that will assist teachers with multicultural education and diversity in schools and particularly in classrooms. Mda (2000) states that the teacher is a crucially important factor in integration. Training is needed in our schools on matters concerning diversity and multiculturalism. As some teachers believe in the data collected that the training will actually help in removing some stereotypes and prejudices held by some teachers. Again, a considerable amount of time must be dedicated to the training and properly trained, well-qualified and knowledgeable trainers must be appointed for this important task. Teachers with experience in the field might be of great help to the training.

\subsection{Other initiatives on integration}

Different kinds of initiatives must also be considered such as workshops, conferences, seminars on teachers and diversity, school integration and multiculturalism. Teachers need to understand diversity and school integration. Therefore 
for this to happen, skills need to be communicated to them, important issues highlighted and adequate tools introduced to assist their understanding. We need to make the teachers understand that South Africa needs the kind of education that can eliminate racism, prejudices and stereotyping not only amongst learners in schools but also amongst teachers.

\subsection{Community involvement on integration}

In addition, the government's involvement and initiatives must be not only in policy development but also in community programmes that will assist in integrating the society at large. Transformation starts with the society and extends to other sectors such as the economy, culture, education and other important elements that make up a positive environment for all citizens. I am also of the view that the schools that are integrating cannot break down the gap(s) that exist in the society in a vacuum, but need the involvement of the society at large. Schools alone cannot deal with and remedy the situation that has a long history of inequalities and segregation, but communities need to help at all levels or sectors that opt for positive transformation.

\subsection{Schools as starting point for integration}

It has been realised that the exclusion of issues of conflict, separation and unequal provision of societal elements from schools is unrealistic and that societal divisions need to be addressed at the schools as an initiative to remedy societal conflict. Although schools should not deal alone with issues of conflict and societal problems, they can serve as a starting point for social change and assistance with development and societal attitude change. This means schools must be encouraged to include issues of integration in their curriculum.

\section{Conclusion}

This article addressed the indispensability of school integration in South African multicultural schools. This is accentuated in the article through stipulating and highlighting succinct discussions of policies assumed to assist school integration. The paper further focused on the challenges of school integration specifically with regards to the gap that exists between policy formulations around school integration and its implementation at school level. Data was gathered from school principals through one-on-one interviews on their views over integration policies as well as on general educational transformation policies in former mono-cultural school especially with regards to policy implementation. Most acknowledged the challenges they are facing with regard to integration and the low rate at which it is progressing. They highlighted that integration should take its own discourse without any intervention.

Furthermore, one can come to a conclusion that transformation was and to some extent still is, as some argue, a challenge to many South Africans. Having to adapt to a new political environment, adopting new policies which are changed or amended all the time means a change of the way of life for the previously privileged as well as the previously disadvantaged. John-Hill (1998) states that in South Africa, the challenge of transformation has always been predominantly a moral struggle which is rooted within racial divisions. Transformation is aimed at establishing democratic norms and standards for all, eliminating these racial divisions and ensuring that all citizens are treated as equal before the law. Hence the paper is addressed this transformation and its progress particularly in education. The expectations for many, is that it is in the hands of the schools to make sure they implement the expectations as set out by the government. Society still expects the school managers to initiate the course of action at the school level. Educators are also expected to play a certain role in implementing the process and assisting the school managers in this regard. Provisions are clearly outlined in policies and legislation as outlined earlier. These are initiatives of the South African government to bridge the gap that existed before and to instil equality amongst all citizens. These policies also assisted and still to a larger extent assisting schools with transformation.

\section{References}

Allais, S. M. (2006). Problems with qualification reform in senior education in South Africa in Young, M and Gamble, J (eds). Knowledge, curriculum and qualifications for South African further education. Cape Town, HSRC Press.

Babbie, E. \& Mouton, J. (2001). The practice of social research. South African edition. Cape Town: Oxford University Press.

Bray, E. (2004). Constitutional perspectives on integration in South African schools in Nkomo,

M.,McKinney, C. and Chisholm, L. (eds). Reflections on school integration: colloquium proceedings. South Africa Human Sciences Research Council, HSRC Publishers.

Carrim, N. (2002). 'Inclusion / Exclusion in South African Education', Institute of Development Studies, Sussex, Department for International 
Development, Discussion Paper 2, 3-6.

Chisholm, L. (1997). The restructuring of South African education and training in comparative context in Kallaway, P; Kruss, G; Fataar, A and Donn, G (eds) 1997. Education after apartheid: South African education in transition. Cape Town, UCT Press.

Chisholm, L. (ed). (2004). Changing class: education and social change in post-apartheid South Africa. South Africa: Human Sciences Research Council.

De Vos, A. S. (1998). Research at grass roots: A primer for caring professions. Pretoria: Van Schaik.

Delgado, R \& Stefanic J. (2001) California's racial history and constitutional rationales for race-conscious decision-making in higher education. UCLA. [Online] Available: http:// heinonline.org/HOL (April 22, 2014).

Fleisch, B. D. (2002). Managing educational change: the state and school reform in South Africa. Sandown: Heinemann Publishers.

Greenstein, R. \& Mabogoane, T. (1994). The challenges of transformation in Chisholm, L.,

Motala, S. and Vally, S (eds) 2003. South African education policy review. Sandown, Heinemann Publishers.

Grinnell, Jr. \& Williams, M. (1990). Research in social work: a primer. USA: FE Peacock.

Johnson-Hill, J. (1998). Seeds of transformation: discerning the ethics of a new generation. Republic of South Africa: Cluster Publications.

Ladson-Billings, G. (2009). Foundations of critical race theory. New York: Routledge.

Mda, T. V. (2000). Integrated schooling in Critical issues in South African education - after 1994

(pp. 43-62). (eds) Mda, T. and Mothata, S. Critical issues in South African education - after 1994. Kenwyn: Juta and Company Limited.

Mda, T. V. and Mothata, S. (2000). Critical issues in South African education - after 1994.

Kenwyn: Juta and Company Limited.

Mothata, S. (2000). Developments in policy and legislation in education and training system (pp. 1-20). In Mda, T.V. and Mothata, S. (eds). 2000. Critical issues in South African education - after 1994. Cape Town: Juta and Company.

Naidoo, J. P. (1996). Racial integration of public schools in South Africa: A study of practices, attitudes and trends. University of Natal, Education Policy Unit.

Neuman, W. L. (2003). Social research methods: qualitative and quantitative approaches. (5 $\left.5^{\text {th }} \mathrm{ed}\right)$.

New York: Library of Congress cataloguing-in-publication data.

Nkomo, M., McKinney, C. \& Chisholm, L (eds). (2004). Reflections on school integration: colloquium proceedings. Pretoria: HSRC Publishers.

Nzimande, B. (1997). Foreword in Kallaway, P; Kruss, G; Fataar, A and Donn, G (eds) 1997. Education after apartheid: South African education in transition. Cape Town: UCT Press.

Republic of South Africa Department of Education. (1995) White Paper 1 on Education and Training. Government Gazette (Notice 196 of 1995). Pretoria: Government Printers.

Republic of South Africa (1996). Constitution of the Republic of South Africa Act 108 of 1996. Pretoria, Government Printers. Pretoria: Government Printers.

Republic of South Africa. (1996). South African Schools Act 1996. Pretoria: Government printers.

Republic of South Africa Department of Education. (1996). The National Education Policy Act.

1996. (Number 27). Pretoria: Government Printers.

Republic of South Africa Department of Education. (1996). White Paper 2 on Organisation, Governance and Funding of Schools. Pretoria: Government Printers.

Republic of South Africa Department of Education. (1997). White Paper 3 on A Programme for Transformation of Higher Education. Pretoria: Government Printers.

Republic of South Africa Department of Education. (2001). White Papers 5 on Early Childhood Education: meeting the challenges of early childhood development in South Africa. Pretoria: Government Printers.

Republic of South Africa Department of Education. (2001). Building an inclusive education and training system. Pretoria: Government Printers.

Republic of South Africa Department of Education. (1997). Language in Education Policy. Pretoria: Government Printers.

Republic of South Africa. (1996). Department of Labour. 1998. Employment Equity Act No. 55 of 1998. Pretoria: Government printers.

Republic of South Africa Department of Education. (1996). Norms and Standards for Educators (amended 2000). (Vol. 415, No. 20844). Pretoria: Government printers.

Republic of South Africa Department of Education. (1996). The National Education Policy Act. 1996. (Number 27). Pretoria: Government printers.

Republic of South Africa Department of Education. (2001). Education White Paper 6 on 'Building an inclusive education and training. Pretoria: Government printers.

Republic of South Africa, Department of Education on Education for all - 2005 Country Status Report: South Africa. Pretoria: Government printers.

Republic of South Africa, Department of Education. (2005). Teachers for the future: meeting teacher shortages to achieve education for all, The National policy framework for teacher education and development in South Africa "more teachers; better teachers". Pretoria: Government printers.

Republic of South Africa. (1984). The National Policy for General Affairs Act (No. 76) of 1984.

Pretoria: Government printers.

Sekete, J., Shilubane, M. \& Moila, B. (2001). Deracialisation and migration of learners in South African schools: challenges and implications. A research project undertaken by the Unit for System Studies, Group Education and Training. Pretoria, Human Sciences Research Council.

Soudien, C. (2004). 'Constituting the class': an analysis of the process of 'integration' in South African schools', in Changing class: education and social change in post-apartheid South Africa, Chisholm, L (ed). South Africa. Human Sciences Research Council.

Sujee, M. (2004). Deracialisation of Gauteng schools - a quantitative analysis in Reflections on school integration: colloquium proceedings Nkomo, M., McKinney, C. and Chisholm, L. (eds). South Africa Human Sciences Research Council, HSRC Publishers.

Vally, S. \& Dalamba, Y. (1999). Racism, 'Racial integration' and Desegregation in South African public secondary schools. A report by the South African Human Rights Commission.

Wiersma, W. \& Jurs, S. G. (2005). Research methods in education: An introduction. (8th ed). USA: Library of Congress cataloguing-in-publication data. Zafar, S. (1997). School-based Initiatives to Address Racial and Cultural Diversity in New Integrating Public Schools. Durban: Education Policy Unit. 